DOI: https://doi.org/10.32838/2523-4803/70-2-19

удК 334

\title{
Москаленко Н.В.
}

кандидат економічних наук, доцент кафедри банківської справи та фінансового моніторингу, Університет державної фіскальної служби України

\section{Moskalenko Nataliia}

University of State Fiscal Service of Ukraine

\section{СВІТОВИЙ ДОСВІД ПОБУДОВИ СИСТЕМИ ЗАПОБІГАННЯ ТА ПРОТИДІЇ ЛЕГАЛІЗАЦІЇ ДОХОДІВ, ОТРИМАНИХ ЗЛОЧИННИМ ШЛЯХОМ, І ФІНАНСУВАННЯ ТЕРОРИЗМУ}

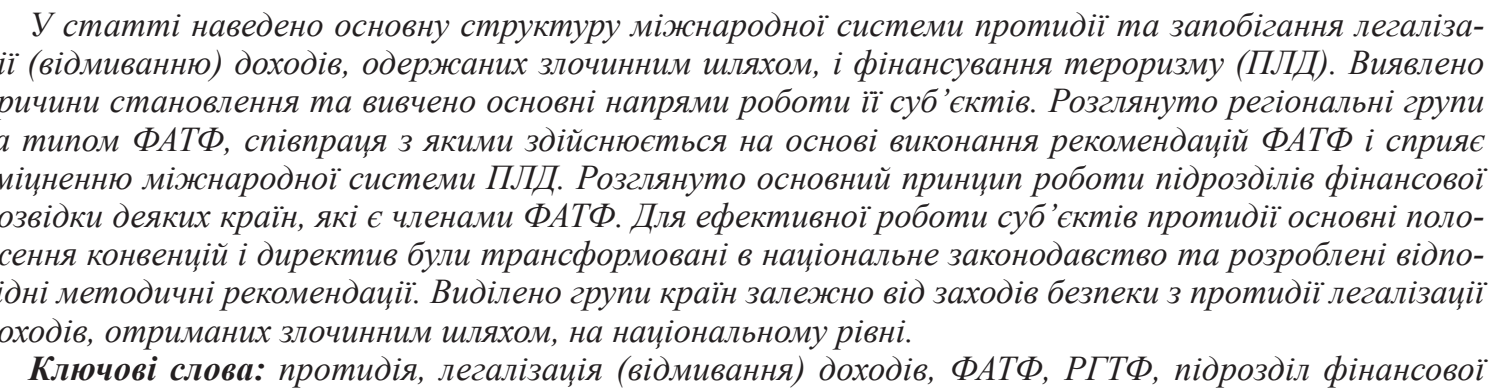
розвідки.

Постановка проблеми. Сьогодні більшість країн світу застосовує національні заходи для протидії легалізації доходів, отриманих злочинним шляхом, у межах яких функціонують їхні системи фінансового моніторингу. Міжнародні стандарти у сфері протидії легалізації доходів злочинного походження стали правовим фундаментом для створення національної системи фінансового моніторингу (СФМ) у кожній окремій державі.

Національні СФМ видозмінюються залежно від багатьох чинників, серед яких варто виділити моделі організації підрозділів фінансового моніторингу, їхні інформаційні зв'язки 3 контролюючими та правоохоронними органами, розподіл контрольних повноважень серед них, систему процедур фінансового моніторингу, систему інформування, відповідальність за порушення законодавства у цій сфері та необхідність його постійного вдосконалення [3].

Аналіз останніх досліджень і публікацій. Питання протидії легалізації доходів злочинного походження (далі - ЛДЗП) знайшло своє відображення у зарубіжній та вітчизняній фінансовій і юридичній науці та практиці, де широко відомі своїми працями такі вчені, як: Д. Брандоліно, О. Барановський, О. Бережний, І. Д'яконова, С. Сгоричева, А. Сжов, М. Єрмошенко, О. Користін, К. Коттке, В. Ларичев, М. Прошунін, Л. Фітуні та ін. Зусиллями цих учених та практиків виявлено загальні закономірності організації схем і моделей відмивання коштів, визначено базові підходи до організації систем протидії легалізації злочинних доходів.

Ураховуючи постійне вдосконалення інструментарію, схем, методів і підходів до відмивання коштів, формування системи протидії негативним процесам у зазначеній сфері потребує більш глибокого вивчення.

Як показує практика, трансформації вітчизняної системи протидії легалізації доходів, отриманих протиправним шляхом, не завжди йшли в ногу з міжнародними вимогами та стандартами, що призводило до зарахування України до «чорного» та «сірого» списків країн, які не співпрацюють у зазначеній сфері. Таким чином, аналіз та адаптація передового досвіду організації даної системи $є$ першочерговим завданням щодо підвищення ефективності їі функціонування.

Формулювання цілей статті. Метою статті $\epsilon$ дослідження теоретико-організаційних засад діяльності та взаємодії суб'єктів системи протидії відмиванню злочинних коштів із метою адаптації найкращих методик для вдосконалення заходів у сфері протидії легалізації доходів, отриманих злочинним шляхом, у вітчизняних умовах.

Виклад основного матеріалу. Серед найбільш значимих міжнародних нормативних документів у даній сфері є Статут ООН, Конвенція ООН про боротьбу проти незаконного обігу наркотичних засобів і психотропних речовин. Згідно із цією Конвенцією, протидія легалізації доходів $є$ одним із заходів боротьби з правопорушеннями, пов'язаними з незаконним обігом наркотиків. 
Подальша робота щодо розроблення міжнародних актів, спрямованих на протидію легалізації, доходів була продовжена регіональною міжнародною організацією - Радою Європи. У 1990 р. підписано Конвенцію Ради Європи про відмивання, виявлення, вилучення і конфіскацію доходів від злочинної діяльності [3, с. 94]. Цим актом закріплене поняття «відмивання грошових коштів»; окрім того, у Конвенції містяться додаткові положення відносно методів протидії.

Починаючи з 1991 p. ЄС послідовно приймає директиви, що встановлюють єдині правила і заходи щодо протидії легалізації грошових коштів і фінансуванню тероризму для всіх країн, які входять в Свропейський Союз. Так, було прийнято три директиви, впроваджені поступово в національні законодавства європейських держав. Таким чином, було визначено коло професійних сфер та інститутів, зобов'язаних здійснювати заходи заборони анонімних рахунків, легалізація грошових коштів уведена в законодавство європейських країн як кримінальне діяння. У зв'язку 3 прийняттям Європейським Союзом четвертої Директиви щодо запобігання використанню фінансової системи у цілях легалізації злочинних доходів і фінансування тероризму в нормативних документах країн сталися істотні зміни.

Основну роль серед міжнародних організацій у даній сфері відіграє Організація Об'єднаних Націй $(\mathrm{OOH})$. У структуру ООН входять декілька особливих підрозділів та декілька самостійних організацій, метою яких є діяльність, спрямована на ПЛД/ФТ. Головне місце серед цих підрозділів (організацій) займає управління Організації Об'єднаних Націй (OOH) по наркотиках і злочинності. У рамках ООН у 1998 р. була створена GPML (Міжнародна програма протидії відмиванню грошових коштів). Цим управлінням була розроблена Глобальна програма ООН у сфері боротьби 3 незаконним відмиванням грошових коштів [1, с. 15].

Україна запроваджує основні міжнародні документи в даній сфері, зокрема Конвенцію Ради Свропи про відмивання, пошук, арешт і конфіскацію доходів, отриманих злочинним шляхом; Конвенцію ООН про боротьбу проти незаконного обігу наркотичних засобів і психотропних речовин; Конвенцію ООН проти транснаціональної організованої злочинності. Для їх ефективного застосування основні положення конвенцій трансформовано в національне законодавство та розроблено відповідні методичні рекомендації.

Основним міжурядовим органом для боротьби з відмиванням грошей $є$ FATF (Financial Action Task Force (Група розроблення фінансових заходів із боротьби 3 відмиванням грошей, далі - ФАТФ)), створений у Парижі (Франція), на саміті країн Великої сімки в 1989 р. Сучасною особливістю регулювання протидії відмиванню (легалізації) злочинних доходів і фінансуванню тероризму є розроблення міжнародних актів рекомендаційного характеру спеціалізованими міжнародними організаціями. ФАТФ виробила рекомендації, що передбачені для країн світової спільноти: визна- чення переліку правопорушень із легалізації доходів; визначення переліку організацій (переважно фінансово-кредитних і поштових), які повинні проявляти особливу пильність під час здійснення через них великих або підозрілих операцій; визначення порядку екстрадиції осіб, звинувачених у легалізації грошей; установлення в законодавстві тієї або іншої країни поняття «легалізація незаконно отриманих доходів» так, що унеможливлювало б двояке тлумачення, суперечки або уникання відповідальності за скоєння цього правопорушення, і т. д. [4, с. 75]. Рекомендації передбачають «міжнародні стандарти 3 питань протидії легалізації (відмиванню) доходів, отриманих у результаті податкових правопорушень, а також доходів від корупційної діяльності; посилення вимог до прозорості здійснюваних клієнтами фінансових установ операцій, ідентифікації їх активів і встановлення структури реального володіння юридичними особами; посилення вимог відносно ідентифікації клієнтів фінансових установ; установлення обов'язковості застосування ризик-орієнтованого підходу під час відстежування операцій клієнтів фінансовими інститутами» [3, с. 115].

ФАТФ здійснює узгодження всіх своїх дій з ООН, Всесвітнім банком, Радою Свропи, МВФ, СБРР, Інтерполом, Радою митної співпраці та іншими міжнародними організаціями. ФАТФ має три робочі групи: перша веде статистичний облік і вивчення схем та методів легалізації грошових коштів, які використовують злочинці; друга спеціалізується на юридичних питаннях; третя розробляє рекомендації та конкретні пропозиції у сфері адміністративно-фінансових заходів із ПЛД/ФТ[4].

Основні напрями в діяльності ФАТФ: розроблення рекомендацій у сфері протидії відмиванню коштів; оцінка відповідності всіх національних законодавств i сучасної практики у сфері боротьби з легалізацією доходів; організація та подальше проведення на постійній основі в країнах симпозіумів, семінарів і конференцій із законодавчих і фінансових проблем; формування в різних країнах регіональних організацій, які споріднені за спрямованістю своєї діяльності з ФАТФ. Щорічно даною організацією формується «чорний список» держав, які не застосовують належних заходів протидії легалізації доходів, отриманих злочинним шляхом, не розвивають законодавчу базу, спрямовану на регламентацію цієї сфери економіки.

Очевидно, що рекомендації не $є$ документами, котрі мають юридичну силу, проте не варто недооцінювати їхній вплив на становлення та розвиток сфери протидії відмиванню доходів. Рекомендації ФАТФ дієві в силу того, що більшість держав дотримується iï норм і санкцій до таких держав, що не виконують рекомендації. Законодавство розвинених країн дає змогу заарештовувати грошові кошти на коррахунках іноземних банків і застосовувати інші дієві економічні й адміністративні заходи. Рекомендації ФАТФ орієнтують кредитні організації звертати особливу увагу на всі заплутані, великі операції, на всі незвичайні за 
своєю структурою угоди, які не мають явного економічного сенсу або очевидної законної мети, оскільки такі операції досить часто здійснюються на першій стадії відмивання незаконних доходів.

Сфера діяльності Інтерполу нині охоплює 181 країну світу. Інтерпол - друга за своєю чисельністю міжнародна організація після ООН. Міжнародне співтовариство поставило перед Інтерполом такі завдання: зменшення усієї міжнародної організованої злочинності за допомогою координації дій з ії розслідування на національному і міжнародному рівнях; підвищення якості та інтенсивності міжнародної співпраці шляхом розширення інформаційного обміну між країнами; стандартизація всіх методів, які застосовуються правоохоронними органами країн у процесі збору, аналізу, зберігання і використання доказової інформаційної бази про злочинну діяльність [3, с. 65].

Кульмінацією багаторічних зусиль країн і міжнародних організацій для протидії відмиванню коштів стало створення Егмонтської групи, яка об'єднує фінансові розвідки різних країн світу Вона функціонує $з$ метою загальної координації діяльності фінансових розвідок.

Важливу роль відведено Організації економічного співробітництва і розвитку (ОЕСР). В організацію зараз входять 35 країн, більшість із цих держав члени Євросоюзу. Також у роботі організації окрему роль відведено Європейській Комісії (як органу Євросоюзу). Здійснює ОССР величезну аналітичну роботу, виробляє спеціальні рекомендації для всіх країн-членів, а також служить певною платформою проведення багатосторонніх переговорів про економічні проблеми. Величезна частка діяльності ОЄСР пов'язана з протидією відмиванню злочинних грошових коштів, ухиленню від сплати податків, хабарництву і корупції, за їі участі вироблено рекомендації і механізми, за допомогою яких необхідно зменшувати в існуючій практиці створення в деяких державах зон із м'яким податковим режимом.

Організацій, що беруть участь у протидії відмиванню доходів, регіональні аналоги ФАТФ: Азіатськотихоокеанська група з боротьби з відмиванням грошових коштів; Карибська група з розроблення фінансових заходів у боротьбі з відмиванням грошових коштів; Група 3 боротьби 3 відмиванням грошей у Східній i Південній Африці; Свразійська група протидії легалізації доходів, які отримані злочинним шляхом, і фінансуванню тероризму; Комітет експертів Ради Свропи за оцінкою дієвості заходів боротьби з відмиванням грошових коштів і фінансуванням тероризму [4, с. 194].

Окрім того, у сфері ПЛД/ФТ слід зазначити ще низку міжнародних організацій. Банк міжнародних розрахунків (БМР) - це спеціальна фінансова міжнародна організація, функцією якої є сприяння тісній співпраці серед центральних банків і полегшенню міжнародних розрахунків. Також це центр економічних і грошово-кредитних досліджень. Його засновниками $є$ центральні банки провідних торгових країн.
Міжнародна організація комісій із цінних паперів фінансова міжнародна організація, яка об'єднує національні органи з регулювання ринків усіх цінних паперів. Заснована організація у 1974 р. $з$ метою постійного стимулювання міжвідомчої співпраці комісій із цінних паперів країн Південної і Північної Америки. У 1984 р. ця організація з регіональної переросла в міжнародну організацію. У 1986 р. ухвалено резолюцію, в якій були закріплені положення, які зобов'язували національні комісії із цінних паперів надавати всіляку допомогу в межах своєї організації у сфері захисту прав інвесторів і контролю над діяльністю усіх посередників, що торгують цінними паперами, і посередників, що здійснюють продаж та купівлю ф'ючерсного контракту. Регулюють члени організації ринки цінних паперів, на які припадає майже 95\% світового ринку цінних паперів.

Також великий внесок у ПЛД/ФТ робить Базельський комітет із банківського нагляду [3]. Ще в 1997 р. встановлено основні принципи ефективного банківського нагляду; у 2012 р. видано останню редакцію цих принципів, тобто організація регулярно їх переглядає. Комітет регламентує діяльність банків у сфері ПЛД/ФТ, координує банки у сфері управління ризиками, пов'язаними з виконанням принципу «знай свого клієнта»; останні вказівки були дані в лютому 2016 р., у яких говориться про ефективне управління ризиками відмивання доходів і фінансування тероризму у банківській сфері.

У 2000 р. одинадцять провідних банків світу (Вольфсбергська група) підписали загальні директиви з протидії відмиванню доходів у приватному банківському секторі, у подальшому іменовані як Вольфсбергські принципи. Вони містять пріоритетні напрями політики банків й основні елементи механізмів щодо запобігання використанню банківської системи для легалізації доходів, отриманих злочинним шляхом. В основі політики банку, відповідно до Вольфсбергських принципів, повинне бути правило, згідно з яким банк може встановлювати стосунки тільки 3 тими клієнтами, відносно джерел доходів або фінансування яких може бути підтверджене їх законне походження [4, с. 189].

Водночас Вольфсбергські принципи припускають, що конкретні механізми протидії відмиванню доходів, отриманих злочинним шляхом, можуть визначатися на розсуд банку. Вольфсбергські принципи містять опис необхідних процедур протидії легалізації незаконних доходів: ідентифікація і вивчення клієнтів, особливості роботи $з$ кодованими рахунками й офшорними юрисдикціями, виявлення підозрілих операцій і дії у разі їх виявлення, навчання персоналу, зберігання інформації, проведення постійного моніторингу операцій. Основною рекомендацією регулюючим органам є ефективне використання усіх ресурсів для виявлення сумнівних операцій, які спрямовані на відмивання доходів, отриманих злочинним шляхом. Міжнародним співтовариством однозначно визнано, що всі заходи з ПЛД/ ФТ є потужними інструментами, які досить ефективні у боротьбі з корупцією [3, с. 78]. 
Висновки. Варто виділяти групи країн залежно від заходів безпеки з протидії легалізації доходів, отриманих протиправним шляхом, на національному рівні. До першої групи слід відносити країни, що зарекомендували себе в міжнародних організаціях у сфері ПЛд/ ФТ, і такі, що мають високопрофільні спеціалізовані служби фінансових розвідок.

До другої групи в системі протидії відносяться всі країни, в яких спеціальні органи фінансових розвідок знаходяться на досить невисокому рівні і відносно яких досі $є$ певні зауваження ФАТФ із питань забезпечення безпеки в даній сфері.

До третьої групи належать країни, що містять на своєму просторі офшорні юрисдикції, при цьому включені до «сірого», «темно-сірого» і «чорного» списків. Дані території мають стратегічні недоліки, відносно таких країн розроблений план довгострокових дій з їх усунення [4, с. 37].

Таким чином, нами наведено систему органів у сфері протидії легалізації доходів, отриманих злочинним шляхом, на міжнародному рівні і виявлено головну особливість, яка полягає у тому, що провідну роль у зазначеній сфері відіграє міжнародна організація ФАТФ, яка видає нормативні акти не обов'язкового, а рекомендаційного характеру, акти «м'якого права».
У сучасній світовій практиці вже напрацьованіо дієві механізми протидії відмиванню злочинних доходів і фінансуванню тероризму, схеми співпраці уповноважених органів державної влади, які можуть бути використані й у нашій країні. Результатом цих дій є ціла низка позитивних зрушень у сфері протидії відмиванню злочинно отриманих грошових коштів і фінансуванню тероризму.

На національному рівні основними елементами системи протидії легалізації доходів є: організації й особи, які здійснюють операції з грошовими коштами, наглядові та правоохоронні органи, а також спеціально уповноважений орган фінансового моніторингу (ПФР).

Організація національної системи великою мірою визначає стан та ефективність боротьби 3 відмиванням грошей, економічною злочинністю, поширенням тіньового сектору. Рівень тінізації економіки свідчить про низьку ефективність функціонування національних систем протидії.

Для більш детального висвітлення питання ефективності функціонування національних систем протидії легалізації доходів, отриманих злочинним шляхом, i фінансуванню тероризму необхідне вивчення ступеню адаптації міжнародних рекомендацій у законодавство та впровадження методик у діяльність суб'єктів даної системи, що й визначає предмет подальших досліджень.

\section{Список літератури:}

1. Барановський O.I. «Відмивання» грошей: сутність та шляхи запобігання : монографія. Харків : Форт, 2003. 472 с.

2. Гуржій С.Г., Копиленко О.Л., Янушевич Я.В. Боротьба з відмиванням коштів: правий організаційний і практичний аспект. Київ : Парламентське вид-во, 2005. 216 с.

3. Сгоричева С.Б. Організація фінансового моніторингу в банках. URL : http://pidruchniki.com/68436/bankivska_ sprava (дата звернення: 04.05.2019).

4. Коваленко В.В., Дмитров С.О., Сжов А.В. Міжнародний досвід у сфері запобігання та протидії відмиванню доходів, одержаних злочинним шляхом, та фінансуванню тероризму : монографія. Суми : УАБС НБУ, 2007. 140 с.

5. Користін О.С. Відмивання коштів: теоретико-правові засади протидії та запобігання в Україні : монографія. Київ : Київський національний університет внутрішніх справ, 2007. 448 с

6. Куришко О.О. Аналіз світового досвіду у сфері протидії легалізації доходів, отриманих злочинним шляхом, у контексті можливості його використання в Україні. Фінансовий простір. 2013. № 2(10). С. 8-15.

\section{References:}

1. Baranovsky O.I. (2003) Mistse ryzykiv u systemi finansovoho monitorynhu operatsiy bankivs'koyi ustanovy [Money laundering: the essence and ways of prevention]. Kharkiv: Fort.

2. Gurzhii S.G., Kopylenko O. L., Janushevich Y.V. (2005) Borot'ba z vidmyvannyam koshtiv: pravyy orhanizatsiynyy i praktychnyy aspekt [Combating money laundering: the right organizational and practical aspect]. Kyiv: Parliamentary View.

3. Egoricheva S. B. (2014) Orhanizatsiya finansovoho monitorynhu v bankak [Organization of financial monitoring in banks]. Available at: http://pidruchniki.com/68436/bankivska_sprava (accessed: 04 May 2019).

4. Kovalenko V., Dmytrov, Yezhov A. V. (2007). Mizhnarodnyi dosvid u sferi zapobihannia ta protydii vidmyvanniu dokhodiv, oderzhanykh zlochynnym shliakhom, ta finansuvanniu teroryzmu [International experience in the prevention and combating of money laundering and terrorist financing]. Sumy: UABS NBU.

5. Koristin O.E. (2007) Vidmyvannya koshtiv: teoretyko-pravovi zasady protydiyi ta zapobihannya v Ukrayini [Money Laundering: Theoretical and Legal Principles of Counteraction and Prevention in Ukraine]. Kyiv: Kyiv National University of Internal Affairs.

6. Kuryshko, O. (2013). Analiz svitovoho dosvidu u sferi protydii lehalizatsii dokhodiv, otrymanykh zlochynnym shliakhom, u konteksti mozhlyvosti yoho vykorystannia v Ukraini [Analysis of world experience in combating the legalization of proceeds of crime, in the context of the possibility of its use in Ukraine]. Finansovyi prostir, no. 2 (10), 8-15. 


\section{МИРОВОЙ ОПЫТ ПОСТРОЕНИЯ СИСТЕМЫ ПРЕДУПРЕЖДЕНИЯ И ПРОТИВОДЕЙСТВИЯ ЛЕГАЛИЗАЦИИ ДОХОДОВ, ПОЛУЧЕННЫХ ПРЕСТУПНЫМ ПУТЕМ, И ФИНАНСИРОВАНИЮ ТЕРРОРИЗМА}

В статье представлена основная структура международной системы противодействия и предотвращения легализачии (отмыванию) доходов, полученных преступным путем (ПОД). Выявлены причины ее становления и изучены основные направления работы ее субъектов. Рассмотрены региональные группы по типу ФАТФ, сотрудничество с которыми осуществляется на основе выполнения рекомендащий ФАТФ и способствует укреплению международной системы ПОД. Рассмотрен основной приниип работы подразделений финансовой разведки некоторых стран, являюшихся членами ФАТФ. Для эффективной работы субъектов противодействия основные положения конвенций и директив были трансформированы в начиональное законодательство и разработаны соответствуюшие методические рекомендации. Выделены группы стран в зависимости от мер безопасности по противодействию легализации доходов, полученных преступным путем, на национальном уровне.

Ключевые слова: противодействие, легализация (отмывание) доходов, ФАТФ, РГТФ, подразделение финансовой разведки.

\section{WORLD EXPERIENCE OF CONSTRUCTING A SYSTEM OF PREVENTION AND COUNTERING THE LEGALIZATION OF INCOME OBTAINED BY CRIMINAL MEANS AND THE FINANCING OF TERRORISM}

The article presents the main structure of the international system of countering the legalization (laundering) of criminal proceeds (AML). The causes of its formation are revealed, and the main subjects are studied. Regional groups of the FATF type are considered, cooperation with which is based on the implementation of the FATF Recommendations, and contributes to the strengthening of the international AML system. And also, the basic principle of the work of the financial intelligence units of some countries that are members of the FATF. Groups of countries are identified depending on security measures to counter the legalization of proceeds of crime at the national level. The purpose of the article is to investigate the theoretical, organizational and legal foundations of the activity and interaction of subjects in the process of counteracting the legalization (laundering) of proceeds from crime and terrorist financing. The aim of the article is research of theoretical and organizational principles of activity and cooperation of subjects with the aim of adaptation of the best methodologies for the improvement of events in the field of counteraction to legalization of the acuestss got a criminal way in home terms. The research was conducted using a set of methods and methods of scientific knowledge. The abstract-logical method has allowed to reveal the theoretical aspects. It costs to distinguish the groups of countries depending on safety measure from counteraction to legalization of acuestss got by a criminal way at national level. To the first group it follows to take countries that showed oneself in international organizations in this sphere, and such that the profile specialized services of financial secret services have highly. To the second group entire countries in that the special organs of financial secret services are at not high enough level belong in the system of counteraction, and relatively to that until now there are certain remarks of FATF on questions providing of safety in this sphere. That contain on the space the offshore jurisdictions, here included to "grey", "darkly-grey" and "black", behave to the third group.

Key words: counteraction, legalization (laundering) of income, FATF, RGTF, financial intelligence unit. 